\title{
Variability of macrofauna distribution along a dissipative log-spiral sandy beach in Rio de Janeiro, Southeastern Brazil
}

\author{
Carlos A.M. Barboza ${ }^{1,2}$, Tatiana Cabrini ${ }^{1,3}$, Gustavo Mattos ${ }^{3}$, Viviane Skinner ${ }^{1}$, \\ Ricardo Cardoso ${ }^{1}$

\begin{abstract}
${ }^{1}$ Departamento de Ecologia e Recursos Marinhos, Universidade Federal do Estado do Rio de Janeiro (UNIRIO), Caixa Postal 20290240, Av. Pasteur n296, Urca, Rio de Janeiro - RJ, CEP 22290-240, Brasil.

(TC) E-mail: tatianacabrini @ gmail.com. ORCID iD: http://orcid.org/0000-0003-2006-7328

(VS) E-mail: vivianeskinner@ hotmail.com. ORCID iD: http://orcid.org/0000-0003-1343-4214

(RSC) E-mail: rcardoso @ unirio.br. ORCID iD: http://orcid.org/0000-0002-8692-0283

${ }^{2}$ Núcleo em Ecologia e Desenvolvimento Sócio-Ambiental de Macaé, Universidade Federal do Rio de Janeiro, Av. São José do Barreto, 764, São José do Barreto, Macaé - RJ, 27965-045, Brazil.

${ }^{3}$ Programa de Pós-graduação em Ecologia, Universidade Federal do Rio de Janeiro (UFRJ), Caixa Postal 68020,

Av. Carlos Chagas Filho, 373, Cidade Universitária (Ilha do Fundão), Rio de Janeiro - RJ, CEP 21941-971, Brazil.
\end{abstract} \\ (CAMB) (Corresponding autor) E-mail: carlosambarboza@ gmail.com. ORCID iD: http://orcid.org/0000-0002-5922-5410 \\ (GM) E-mail: Gustavo.mattos@ globo.com. ORCID iD: http://orcid.org/0000-0003-3677-4190
}

\begin{abstract}
Summary: Log-spiral beaches display defined physical gradients alongshore. However, the majority of studies focus on the variability of a single population of macrofauna species. We aimed to investigate the variation in species distribution and in community structure along ten transects on a log-spiral beach. Principal component analysis indicated a clear physical gradient alongshore. Redundancy analysis showed that the sheltered end was related to smaller particle sizes, higher organic matter content and high densities of polychaetes. The exposed end was characterized by coarser sand, lower organic matter content and a high presence of crustaceans. Model selection indicated that the "best fit" to explain the variability in the number of individuals included grain size and beach slope. Variability of the polychaete Scolelepis squamata was best explained by grain size, slope and sediment sorting. The best model for the cirolanid Excirolana armata only included sediment sorting. The physical gradient in sediment texture and the beach slope explained more than one-third of the variability in community structure. The physical variables were also correlated with the distribution of the individual species. We showed that the physical gradient on log-spiral coasts may be an important driver of macrofauna variability, even at mesoscales and in dissipative conditions.
\end{abstract}

Keywords: macrofauna assemblage; curved beaches; mesoscale; intertidal; morphodynamic; physical gradient.

Variabilidad en la distributión de la macrofauna a lo largo de una playa disipativa arenosa en espiral en Rio de Janeiro, Sudeste de Brasil

Resumen: Las playas en espiral muestran gradientes físicos definidos a lo largo de su recorrido. En este trabajo se investiga la relación entre la distribución en la estructura de comunidades de la macrofauna de una playa y sus gradientes físicos mediante el estudio de 10 transectos. El análisis de componentes principales reveló un claro gradiente físico a lo largo de la playa. El análisis de redundancia mostró que el extremo protegido se caracterizó con tamaños de grano menor, mayor contenido de materia orgánica y uma mayor densidad de anélidos poliquetos. El extremo expuesto se caracterizó por arena gruesa, bajo contenido de materia orgánica y una alta densidad de crustáceos. El mejor ajuste para explicar el número de individuos en una muestra se relacionó con el tamaño del grano de arena y la pendiente de la playa. La variabilidad del poliqueto Scolelepis squamata se explicó mejor en base al tamaño de grano, la pendiente y la selección de su sedimento. Por su parte, el mejor modelo para explicar la variabilidad del cirolánido Excirolana armata solo incluyó la selección del sedimento. El gradiente físico en la textura del sedimento y la pendiente de la playa explicó más de la tercera parte de la variabilidad en la estructura comunitaria. A su vez, las variables físicas también se correlacionaron con la distribución de especies individuales de la macrofauna. El gradiente físico en las playas en espiral puede explicar la variabilidad de su macrofauna, incluso a mesoescala y en condiciones disipativas.

Palabras clave: facies de macrofauna; playas curvadas; meso-escala; intermareal; morfodinámica; gradientes físicos.

Citation/Como citar este artículo: Barboza C.A.M., Cabrini T., Mattos G., Skinner V., Cardoso R. 2017. Varibility of macrofauna distribution along a dissipative log-spiral sandy beach in Rio de Janeiro, Southeastern Brazil. Sci. Mar. 81(1): 111-120. doi: http://dx.doi.org/10.3989/scimar.04467.03A

Editor: R. Sardà. 
Received: May 2, 2016. Accepted: January 11, 2017. Published: February 15, 2017.

Copyright: () 2017 CSIC. This is an open-access article distributed under the terms of the Creative Commons Attribution (CC-by) Spain 3.0 License.

\section{INTRODUCTION}

Sandy beaches are the most common coastal environment and harbour a specialized biota (Defeo and McLachlan 2005), but they are frequently neglected and poorly represented in studies of marine coastal systems (Defeo and McLachlan 2005, Harris et al. 2014). In ecology, the scale of the investigation plays an important role (Wiens 1989), and understanding the distribution of species at the micro-, meso- and macroscale is a primary goal for conservation and management of sandy beaches (Defeo and Rueda 2002, Schoeman and Richardson 2002, Barboza and Defeo 2015). At the mesoscale (within a beach arc), the community structures and species distribution can be investigated in three dimensions: across-shore (perpendicular to the water mark), alongshore (parallel to the length of the beach) and vertically (from the surface of the sediment layer to greater depths). Because most species live closer to the surface of the sand, the distribution of the macrofauna is two-dimensional: across-shore and alongshore (McLachlan and Brown 2006).

Although the classical zonation patterns on sandy beaches are well established (MacLachlan and Brown 2006), in the 1980s researchers began to qualitatively investigate the ecology and ecophysiology of the sandy beach macrofauna (Defeo and McLachlan 2005). The community descriptors and the zonation patterns of the macrofauna vary within the across-shore dimension. Generally, the distribution of macrofauna is sparse in the surf zone and supralittoral zone, whereas it is more abundant in the intertidal zone (MacLachlan and Brown 2006). Zonation patterns were previously proposed by Dahl (1952) and were based on the typical crustacean fauna that inhabit the three biological zones. Furthermore, based on how the hydrodynamics of the interstitial water changes with shore level, Salvat (1964) defined four physical zones according to the species assemblage found within each zone. Moreover, Dahl's zonation patterns can be easily superimposed on Salvat's physical zones. These zones do not have sharp boundaries and, in fact, often overlap (McLachlan 1983, 1990, Degraer et al. 2003). Historically, most studies have focused on the across-shore zonation patterns of the macrofauna (McLachlan and Jaramillo 1995, Schlacher and Thompson 2013). In contrast, fewer studies have investigated the alongshore distribution of macrofauna on sandy beaches. The species distribution alongshore is dependent on the spatial scale investigated, which may be patchy, asymptotic or bell-shaped, and varies according to the morphodynamic states (McLachlan and Hesp 1984, Giménez and Yanicelli 2000, Defeo and de Alava 1995). Usually, species density is high in the central portions of the beach arc and decreases towards one or both ends (MacLachlan and Brown 2006). The macrofauna distribu- tion alongshore is related to several physical factors, including the presence of freshwater discharge (Lercari and Defeo 2003, Gandara-Martins et al. 2014), the morphology and water circulation of the sandy beach (McLachlan and Hesp 1984, Donn 1987, Giménez and Yanicelli 2000), the particle grain size and the slope (McLachlan 1996, Lastra and McLachlan 1996, Fernandes and Soares-Gomes 2006). In addition, biotic factors, such as food availability, settlement behaviour and intra/interspecific competition, also play a role in the alongshore distribution of macrofauna and may interact with the physical variables (Ansell 1983, Defeo and de Alava 1995, Schoeman and Richardson 2002). Studies have also shown that human-induced variability, such as the presence of seawalls and revetments, drives variation in macrofauna distribution (Dugan and Hubbard 2010).

The alongshore variability in beach exposure is an important variable that influences the distribution of intertidal species. Spiral bays or log-spiral beaches display more clearly defined physical gradients along the sheltered narrow end than at the more exposed open end. This pattern is generated by the interaction between the wave energy, the grain size and the beach face slope (LeBlond 1979, Bremmer 1983). Because the sand texture and swash flow are the two most important factors that define the beach habitat of benthic macrofauna, the distribution of macrofauna varies along this physical gradient (McLachlan 2001). Furthermore, the species composition and abundance also respond to morphodynamic variables and decrease alongshore with increasing beach slope and grain size (Degraer et al. 2003).

The majority of studies investigating the distribution of macrofauna along log-spiral bays have focused primarily on the variability of a single species population (Donn 1987, Schoeman and Richardson 2002). However, the length of the beach is a significant factor in beach ecology (Brazeiro 1999), so the limited number of studies concerning the community variability on a single log-spiral beach is particularly evident for shortened physical gradients $(<1 \mathrm{~km}$ long). Different processes operating at multiple spatial scales differentially affect the distribution of species along the beach (Giménez and Yanicelli 2000, Rodil et al. 2012). It is believed that on large scales, the macrofauna is mainly controlled by the physical environment (Defeo and McLachlan 2005), whereas biological factors are a very important driver of species distribution on smaller scales and under more dissipative conditions (Defeo et al. 2003, McLachlan and Dorvlo 2005). However, Rodil et al. (2012) showed that sediment characteristics and the beach face slope showed the highest contribution to explaining most of the macroinvertebrate community variation at the mesoscale. Therefore, in this study, we investigated the species distribution along a dis- 

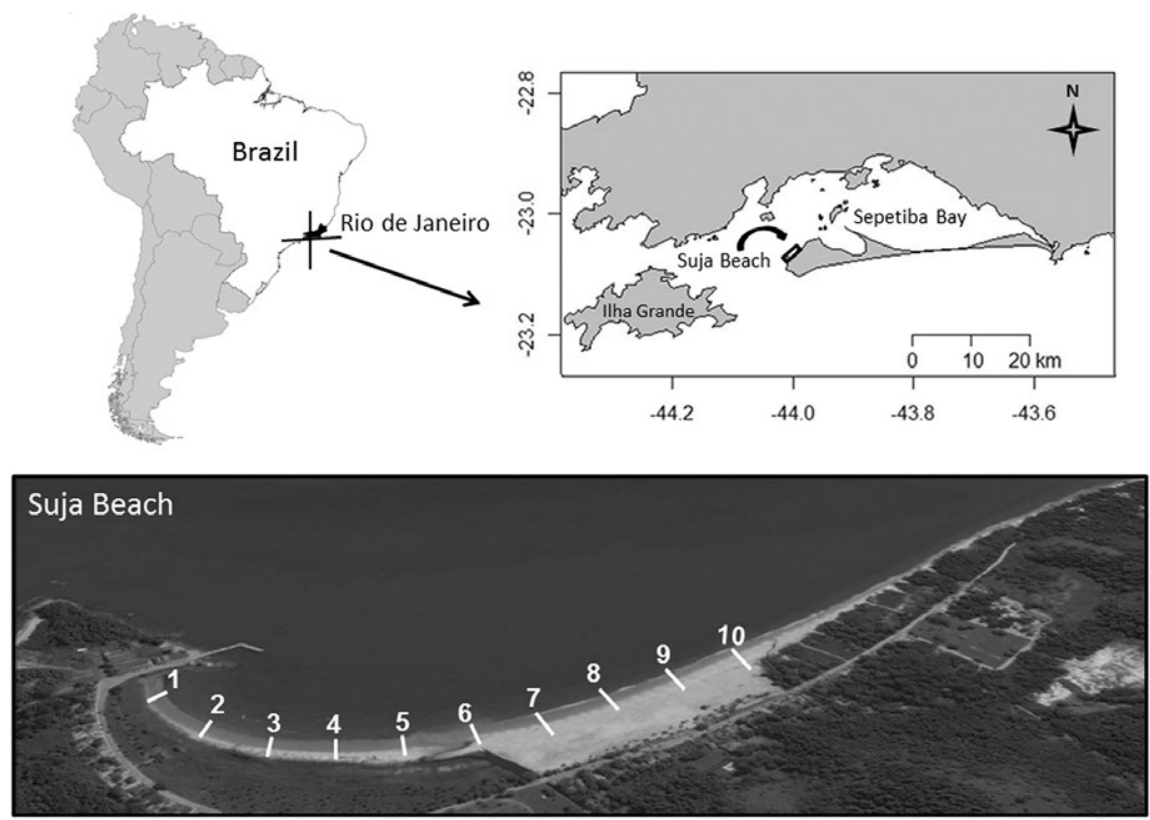

Fig. 1. - Sepetiba Bay (upper panel) and Suja Beach with the locations of the ten transects sampled along the beach arc.

sipative log-spiral beach located on the southern coast of Brazil. We hypothesized that the physical gradient would be an important driver of species distribution on short, dissipative log-spiral beaches. Furthermore, because log-spiral beaches display a defined gradient of exposure and sediment texture, we predicted that even at limited spatial scales (hundreds of metres) the macrofauna variability at both the population and community level would strongly correlate with the physical gradient, as measured by the sediment texture and beach face slope.

\section{MATERIALS AND METHODS}

\section{Study area}

Sepetiba Bay (Fig. 1) is located on the coast of Rio de Janeiro State in southeastern Brazil and has a surface area of $450 \mathrm{~km}^{2}$. It is a sedimentary embayment that is shaped by extensive processes of sand deposition. Based on the environmental characteristics, the bay can be divided into three sectors: the inner sector (influenced by freshwater discharges from several small rivers), the outer sector (influenced by oceanic waters and in contact with the Atlantic Ocean by a wide mouth located at its western end) and the middle sector (a mixed zone with intermediate environmental conditions influenced by freshwater discharges and by oceanic waters). The outer sector is marked by the presence of islands with several sheltered and exposed sandy beaches (Cardoso et al. 2012). The mean tidal range of the region is $1.50 \mathrm{~m}$ and currents, with a maximum speed of approximately $1 \mathrm{~m} / \mathrm{s}$, mainly regulate the hydrodynamic conditions (Fragoso 1999). At its western end, the Sepetiba Bay is connected to Ilha Grande Bay by a narrow channel in which the main current direction is from west to east (Signorini 1980, Fragoso 1999). Cardoso et al. (2012), studying
12 sandy beaches on five islands within Sepetiba Bay, showed that the species richness and total abundance markedly increase in the inner bay, where the wave action is minimal. They also verified that wave exposure variability, sediment variables (e.g. silt-clay content), and the length and width of the beaches had a stronger influence on macrofauna. Suja Beach is located in the outer sector of the bay (facing the continent) and has a beach arc approximately $2 \mathrm{~km}$ long (Fig. 1). It has a Beach Index (McLachlan and Dorvlo 2005) of 2.28 and is classified as a dissipative sandy beach. The dominant south/southwestern winds (Signorini 1980, Fragoso 1999) and the orientation of the beach in relationship to the oceanic swells are responsible for the log-spiral shape of the beach (LeBlond 1979, Bremmer 1983). The beach has a sheltered area at the narrow end and a more exposed area at the open end, creating a defined physical gradient of morphodynamic characteristics and sediment texture. The sheltered end also contains a pier that advances $70 \mathrm{~m}$ into the sea. In the middle area of the beach arc, there is also a small freshwater river mouth.

\section{Sampling procedures and morphodynamic measures}

The sampling was performed in April 2009 along ten equally spaced $(100 \mathrm{~m})$ transects perpendicular to the shoreline. Although this was a snapshot study, we investigated the variability of a well-established morphodynamic feature from a single beach arc. The spatial pattern defined by a protected and an exposed end alongshore is not mutable over time, so we can expect the same main physical influence at different times. Ten equally spaced sampling levels were established on each transect; the first was at the waterline, the second to last was on the drift line and the last was $3 \mathrm{~m}$ above the drift line (supralittoral zone). A total of 
114 - C.A.M. Barboza et al.

Table 1. - Mean values of sediment parameters and beach face slope measured in each transect of Suja Beach. TOM, total organic matter.

\begin{tabular}{rcccccc}
\hline Transect & Grain size $(\mathrm{mm})$ & Sorting & Skewness & Kurtosis & TOM $(\%)$ & Beach slope \\
\hline 1 & 0.103 & 2.581 & -0.100 & 1.019 & 5.406 & 0.037 \\
2 & 0.088 & 2.447 & -0.584 & 1.253 & 1.409 & 0.047 \\
3 & 0.123 & 1.630 & -0.308 & 1.544 & 0.848 & 0.055 \\
4 & 0.157 & 1.672 & 0.032 & 1.356 & 0.822 & 0.040 \\
5 & 0.162 & 1.839 & -0.102 & 1.488 & 0.851 & 0.026 \\
6 & 0.160 & 1.688 & -0.025 & 1.805 & 0.293 & 0.043 \\
7 & 0.198 & 1.794 & 0.207 & 1.110 & 1.028 & 0.070 \\
8 & 0.159 & 1.935 & -0.025 & 1.765 & 0.728 & 0.058 \\
9 & 0.315 & 2.083 & 0.056 & 0.732 & 0.876 & 0.050 \\
10 & 0.339 & 1.942 & 0.054 & 0.780 & 0.226 & 0.078 \\
\hline
\end{tabular}

100 samples were taken at a depth of $25 \mathrm{~cm}$ with a 0.04 $\mathrm{m}^{2}$ quadrat sampler. The collected sediment was sieved through a $0.50 \mathrm{~mm}$ mesh sieve, and the retained material was taken to the laboratory, where the organisms were sorted and fixed in $5 \%$ buffered formalin.

The beach face slope was determined by the height difference (Emery 1961) between the supralittoral zone and the waterline at each transect. Sediment samples for particle size analysis were collected from each transect at four equally spaced levels using a $3.5 \mathrm{~cm}$ diameter corer. The samples were oven-dried at $70^{\circ} \mathrm{C}$ and passed through a series of sieves in order of size and parameters were estimated according to Folk and Ward (1957). The total organic matter (TOM) content was estimated in sub-samples of $5 \mathrm{~g}$ of dried sediment after calcination at $500^{\circ} \mathrm{C}$ for $1 \mathrm{~h}$.

\section{Data analysis}

The biological data were arranged in an $n \times p$ matrix, with the transects in rows and the species in columns. The abundance of each species was calculated by summing up the number of individuals sampled in each level of each transect (Schlacher et al. 2008). Sediment variables were assessed using the grain size, sorting, skewness, kurtosis and content of organic matter, calculated using mean values from five levels $(2,4,6,8$ and 10) of each transect, which provided a point estimate. A principal component analysis (PCA) was used to assess patterns of spatial variation in sediment features and beach slope. A redundancy analysis (RDA) (Rao 1964) was used to link the physical and biological variability. Prior to performing the RDA, the physical matrix (including the sediment parameters and the beach slope) was standardized, and the Hellinger transformation (Legendre and Gallagher 2001) was applied to the biological matrix.

Generalized linear models (GLMs) using a Poisson distribution (Zuur et al. 2009) were adjusted to investigate the variability in the counts of the total number of individuals and the number of individuals from the most abundant species. The models were run using the main morphodynamic descriptors of sandy beaches (particle grain size, beach face slope and sediment sorting) as predictors (Defeo and McLachlan 2005). TOM was excluded as a predictor to avoid model saturation and because it was significantly correlated $(\mathrm{p}<0.05)$ with sediment sorting. To search for the best-fit model to explain the biological variability, we primarily ran a total of eight candidate models (all possible combinations of the additive effects $2^{\mathrm{n}}$, where $\mathrm{n}$ is the number of predictors). Applying a theoretical inference approach, the 'best-fit model' was selected using the corrected Akaike Information Criteria (AICc), log-likelihood scores and Akaike weights (AICw). The weight of each model measured the relative likelihood of a model being the best fit for the given data (Burnham and Anderson 2002). All data analyses were performed using the $R$ program (R Development Core Team 2014) with the assistance of the software packages vegan (Oksanen et al. 2015), MASS (Venables and Ripley 2002) and MuMln (Barton 2014).

\section{RESULTS}

\section{Sediment and morphodynamic variability}

The particle grain size and beach face slope varied alongshore between 0.09 and $0.34 \mathrm{~mm}$ (very fine sand to medium sand) and 0.03 and 0.08 , respectively (Table 1). The first principal component of the PCA analysis showed that there was a clear physical spatial gradient alongshore. The biplot showed a distinct separation between transects 1 and 2 and the other transects. The first ones were characterized by the higher values of organic matter and grain sorting

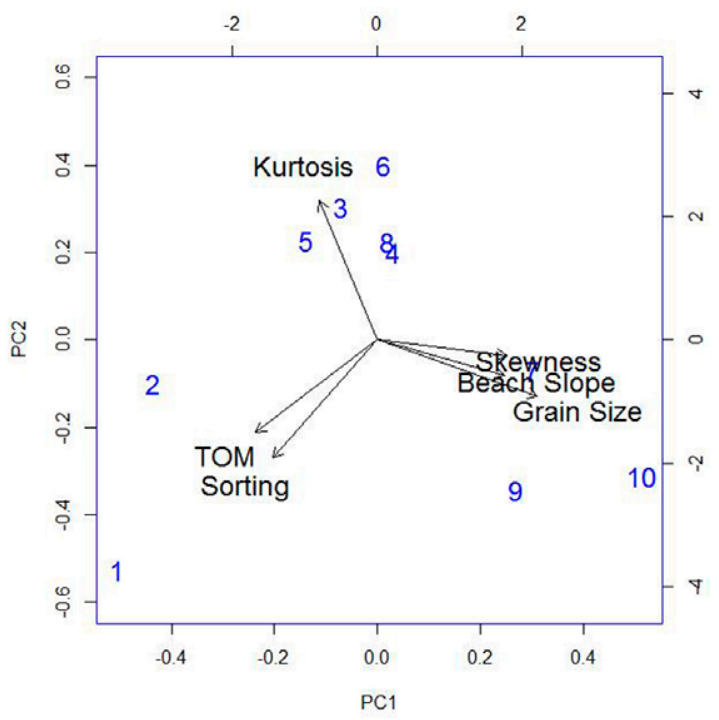

Fig. 2. - Principal component analysis (PCA) plot based on sediment texture and beach face slope. Numbers indicate transects sampled along the beach arc. TOM, total organic matter. 
Table 2. - List of species and number of individuals per transect sampled at Suja Beach.

\begin{tabular}{|c|c|c|c|c|c|c|c|c|c|c|}
\hline & \multicolumn{10}{|c|}{ Transects } \\
\hline & 1 & 2 & 3 & 4 & 5 & 6 & 7 & 8 & 9 & 10 \\
\hline \multicolumn{11}{|l|}{ Polychaeta } \\
\hline Goniadidae & 1 & 5 & 1 & 0 & 0 & 5 & 2 & 0 & 2 & 0 \\
\hline Oenoidae & 1 & 0 & 2 & 0 & 0 & 0 & 0 & 0 & 0 & 0 \\
\hline Orbinidae & 0 & 1 & 24 & 5 & 0 & 0 & 0 & 0 & 0 & 0 \\
\hline Glycera & 0 & 4 & 0 & 0 & 0 & 0 & 0 & 0 & 0 & 0 \\
\hline Magelona & 0 & 0 & 1 & 4 & 0 & 0 & 0 & 0 & 0 & 0 \\
\hline Mooreonuphis & 5 & 0 & 7 & 0 & 0 & 0 & 0 & 0 & 0 & 0 \\
\hline Capitella complex & 60 & 0 & 0 & 0 & 0 & 0 & 0 & 0 & 0 & 0 \\
\hline Owenia fusiformis & 0 & 0 & 1 & 0 & 0 & 0 & 0 & 0 & 1 & 0 \\
\hline Scolelepis squamata & 76 & 115 & 68 & 122 & 46 & 5 & 2 & 76 & 1 & 0 \\
\hline \multicolumn{11}{|l|}{ Crustacea } \\
\hline Caridae & 0 & 0 & 1 & 0 & 0 & 0 & 0 & 0 & 0 & 0 \\
\hline Cheidae & 0 & 0 & 0 & 1 & 0 & 0 & 0 & 0 & 0 & 0 \\
\hline Excirolana armata & 0 & 0 & 1 & 2 & 19 & 21 & 27 & 29 & 1 & 3 \\
\hline Excirolana braziliensis & 0 & 0 & 0 & 0 & 1 & 1 & 1 & 1 & 1 & 0 \\
\hline Emerita brasiliensis & 0 & 0 & 3 & 0 & 1 & 1 & 1 & 0 & 2 & 4 \\
\hline Monokalliapseudes schubarti & 0 & 101 & 0 & 0 & 0 & 0 & 0 & 0 & 0 & 0 \\
\hline Pinnixia chaetopterana & 0 & 0 & 0 & 0 & 0 & 0 & 0 & 1 & 0 & 0 \\
\hline \multicolumn{11}{|l|}{ Mollusca } \\
\hline Anomalocardia flexuosa & 0 & 0 & 1 & 0 & 0 & 0 & 0 & 0 & 0 & 0 \\
\hline Corbula patagonica & 0 & 0 & 1 & 0 & 0 & 0 & 0 & 0 & 0 & 0 \\
\hline Donax hanleyanus & 0 & 0 & 0 & 0 & 0 & 0 & 0 & 1 & 0 & 0 \\
\hline Eurytellina lineata & 17 & 0 & 0 & 0 & 0 & 0 & 0 & 0 & 0 & 0 \\
\hline Olivella minuta & 0 & 0 & 0 & 0 & 0 & 0 & 0 & 0 & 1 & 0 \\
\hline
\end{tabular}
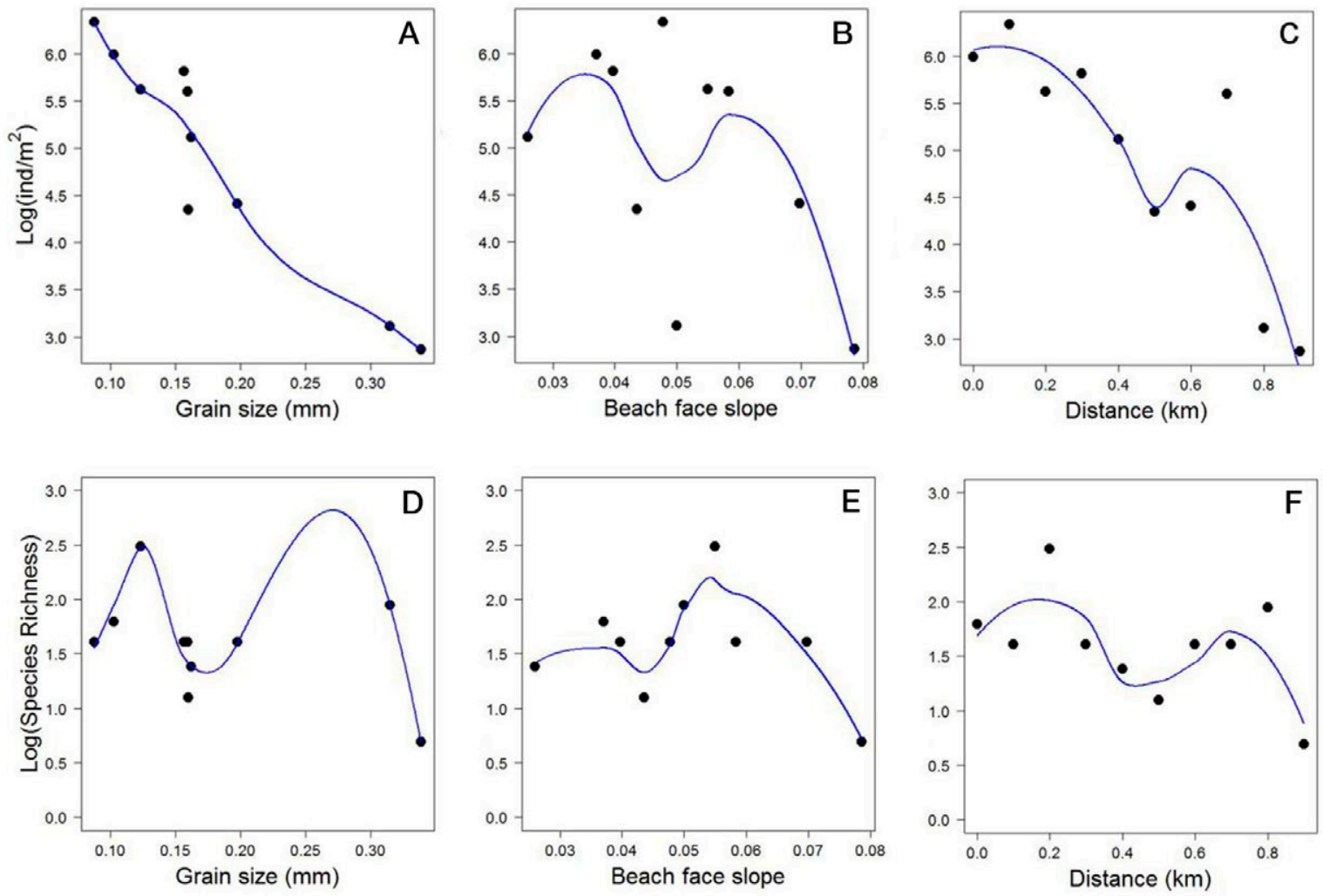

Fig. 3. - Values of individuals $\mathrm{m}^{-2}$ and macrofauna species richness against mean grain size, beach face slope and distance along beach of each individual transect sampled at Suja Beach. The blue lines indicated the LOESS smoothing curve with a span width of 0.75 in each panel.

(Fig. 2). The transects sampled from the middle part of the beach arc (3 to 6) were characterized by higher values of kurtosis measures. This gradient was partially disrupted by the position of transect 8 , which grouped with the middle transects on the central top of the PCA diagram. Transects 7, 9 and 10 were characterized by higher grain size, slope and skewness values (Fig. 2).

\section{Species composition and distribution alongshore}

A total 886 individuals were sampled, and 21 species were identified, which were mainly comprised of polychaetes and crustaceans (Table 2). The most abundant and frequent species was the polychaete Scolelepis squamata $(\mathrm{n}=511)$, which was followed by the cirolanid crustacean, Excirolana armata $(\mathrm{n}=103)$. 


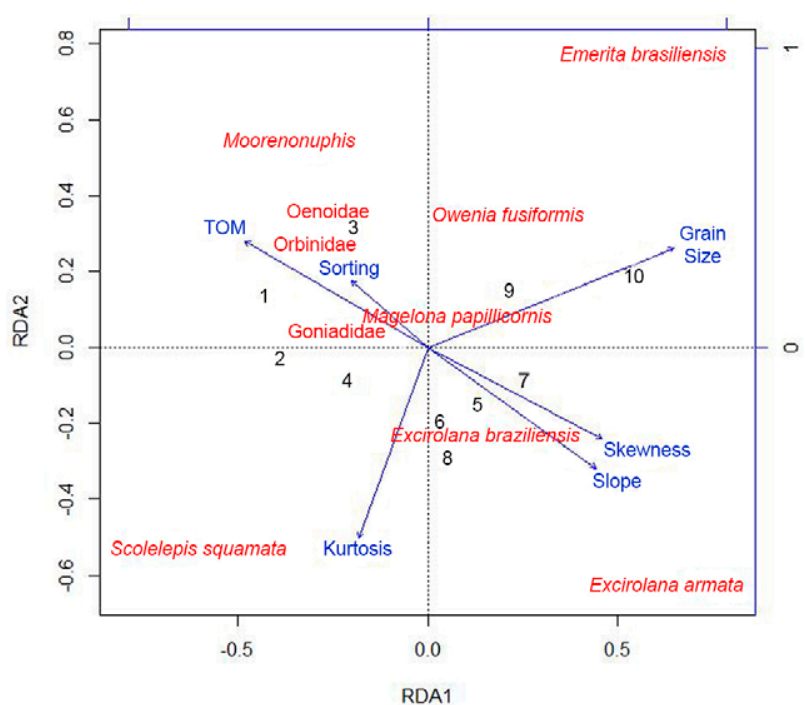

Fig. 4. - Triplot from a redundancy analysis of Suja Beach. Environmental variables are represented by blue arrows, transects by numbers and taxa by names. $\mathrm{R}^{2}$ adjusted $=0.37$.

Figure 3 contains scatter plots showing the patterns over transects alongshore. A LOESS smoothing curve was added in each panel to aid visual interpretation. The total number of individuals decreased as the distance from the sheltered end, the particle grain size and the beach face slope increased (Fig. 3A-C). In addition, the species richness tended to decrease as the distance increased; however, there is no significant trend here and no clear relationship with the grain size and beach slope (Fig. 3D-F).

\section{Relationships between the species distribution and the sediment variability}

The RDA explained $37 \%$ of biological variability. The triplot diagram showed that there were clear differences in the species assemblage and sediment texture alongshore (Fig. 4). The transects from the sheltered end were separated along the first canonical axis by higher contents of organic matter, grain sorting and kurtosis measures. In particular, the organic matter and grain sorting variables were related to the higher abundance of polychaetes. In contrast, the transects from the middle area and the exposed ends had more severe morphodynamic conditions and were plotted on the positive side of the first canonical axis. These transects were dominated by a high level of crustaceans. The second axis separated transects 9 and 10 from transects 5 to 8 by coarser grain sizes (Fig. 4).

The models ranked by their AICc values are shown in Table 3. For the three response variables investigated, all models that included the beach slope or at least one sediment characteristic had a higher likelihood than the respective null model that included only the intercept term. For the total number of individuals, the best-fit model (with an AICc weight equal to 0.513) included the grain size, sediment sorting and an intercept term (Table 3). Figure 5A-B show that the partial effects of grain size and sediment sorting decreased the number of individuals. The second best-fit model excluded sediment sorting and the AICc weight was 0.338. The evidence ratio measures the support for each individual model by taking into account the ratio

Table 3. - Results from all combinations of the possible models adjusted for the total number of individuals, Scolelepis squamata and Excirolana armata sampled at Suja Beach. Models were ordered by AICc values. The numbers in the predictors columns of grain size, beach face slope and sediment sorting are the estimated values of each variable included in the model. Degrees of freedom (df), loglikehood (Loglik), corrected Akaike information criterion (AICc), delta Akaike information criterion (dAIC) and weights from each model were reported.

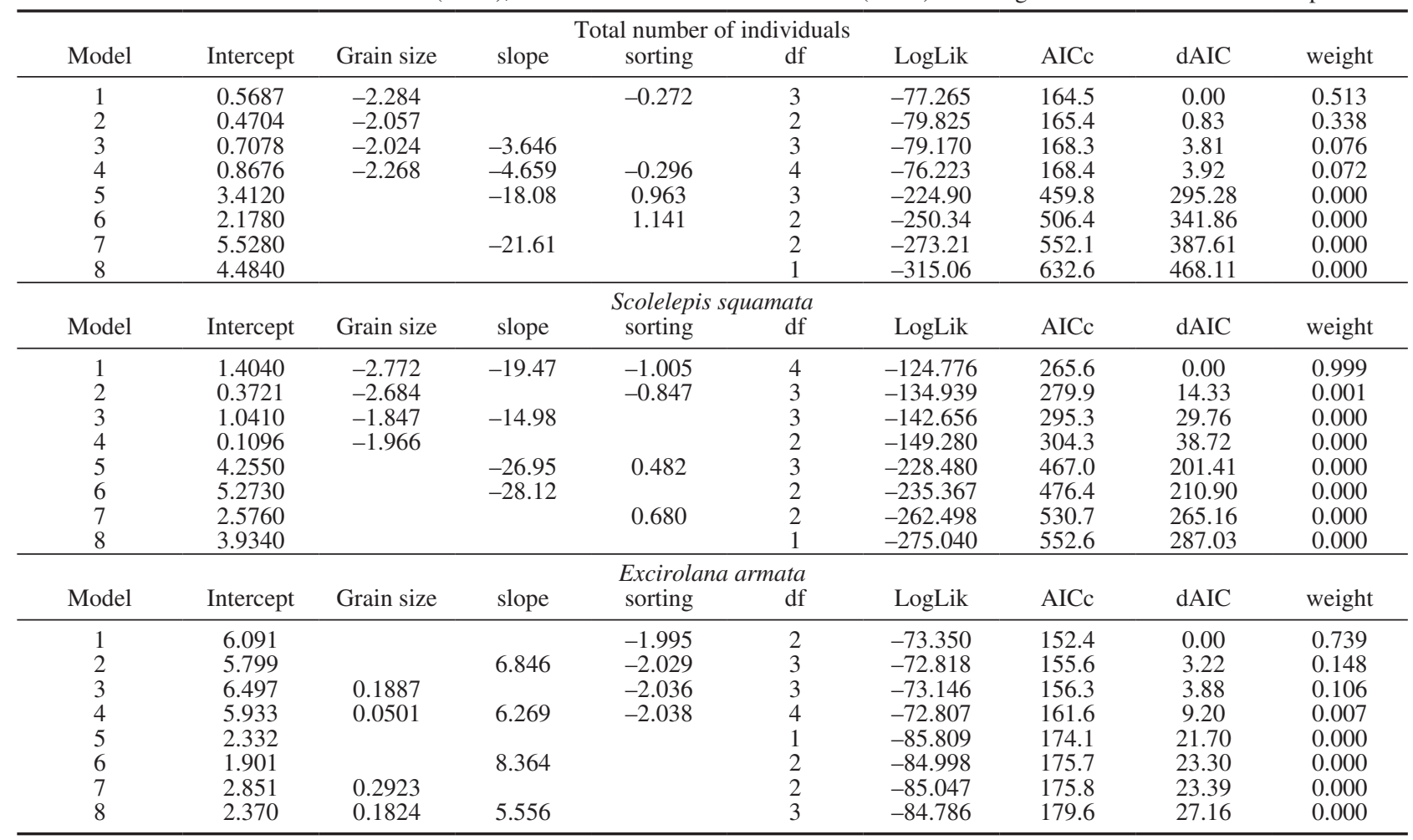



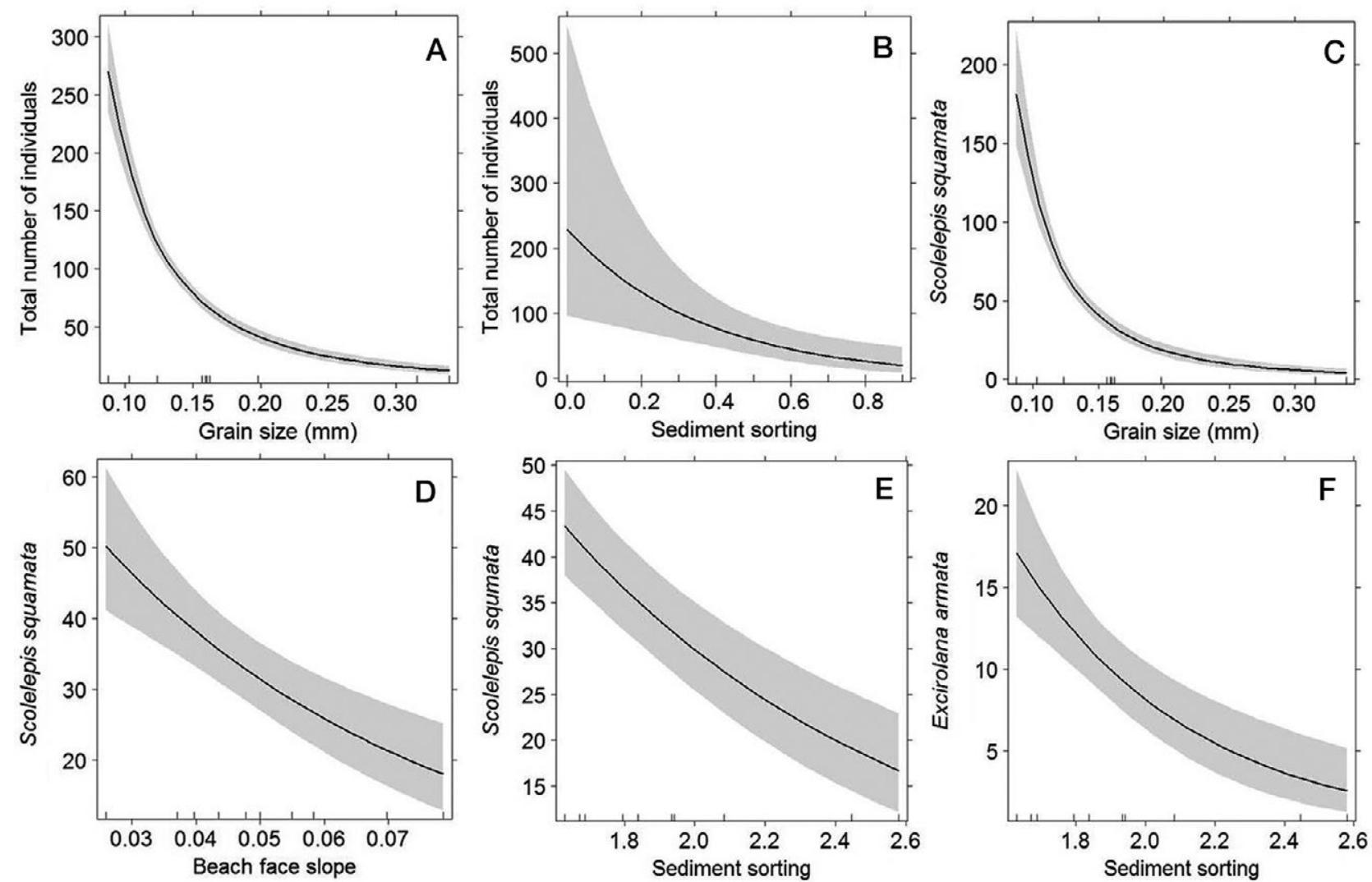

Fig. 5. - Mean partial effects of grain size, beach slope and sediment sorting of generalized linear models adjusted to the total number of individuals, Scolelepis squamata and Excirolana armata sampled at Suja Beach. Only the effects of the variables selected in each best model are shown. Grey shadows indicate the 0.95 confidence interval. The tick marks on the x-axis indicate the measured values for each predictor.

between the weight of the best-fit model and a candidate model (Burnham and Anderson 2002). The ratio between the first and the second best-fit models was 1.52 , which indicates that a parsimonious explanation has the same probability of being the best-fit model. The AICc weights of all the remaining models were less than 0.1 (Table 3). The best-fit model adjusted for the number of $S$. squamata included all the morphodynamic predictors and had an AICc weight of 0.99 , which indicated that this model has a very high probability (99\%) of explaining another data set structured by the same processes (Burnham and Anderson 2002). The three morphodynamic predictors had a negative effect on the abundance of S. squamata (Fig. 5C-E). The best-fit model adjusted to the number of $E$. armata included only sediment sorting (Table 3 ) and had a negative effect on the number of individuals (Fig. 5F).

\section{DISCUSSION}

Our primary hypothesis was confirmed by both the strong correlation between the distribution of macrofauna at the population and community level and the physical variability. The log-spiral shape, in which the beach arc is sheltered at the narrow end and more exposed at the open end, is generated by the slope gradient and the sediment texture along Suja Beach. The sheltered end of the beach was characterized by smaller particle sizes, a higher organic matter content and macrofauna consisting primarily of polychaetes. The exposed end was characterized by coarser sand, a lower organic matter content and a high presence of crustaceans. These data indicate that the physical variables are an important driver of community structure and species distribution, even at mesoscales under dissipative conditions.

At mesoscales, macrofauna communities from the intertidal zone are mainly controlled by physical drivers and may lack a strong biotic control in direction to reflective morphodynamic states (see McLachlan 1990, Brazeiro 2001, Defeo and McLachlan 2005 for a review). The triplot from the RDA indicated that there were clear changes in the community structure and the sediment texture alongshore, which explained more than one-third of the variability in community assemblage. On exposed sandy beaches, the change in response to physical drivers is more variable for species abundance than for species richness (Defeo and McLachlan 2005). In addition, the length of the beach influences species composition at small spatial scales such as pocket beaches $(<2 \mathrm{~km})$; however, this influence decreases as the length of the beach increases (Brazeiro 1999). The relationship between beach length and total species number is not obvious and may be non-linear and scale-dependent (Cardoso et al. 2012). McLachlan (1996) reported that on a 4-km-long beach in Namibia, the species richness and abundance decreased in the central area of the beach arc where the mean sand particle size increased 
due to tailings disposal. However, studying two shorter Brazilian beaches (700 and $900 \mathrm{~m}$ long), Fernandes and Soares-Gomes (2006) found a significant relationship between species abundance, grain size and beach slope, but not species richness. These results are in agreement with our findings on the relationship between species abundance, species richness and the physical variables. Species abundance was higher in the first transects and decreased at the more exposed ends of the beach; therefore, the species abundance was negatively related to the particle grain size. Furthermore, although species richness tended to decrease at the exposed ends of the beach arc, it was not significantly related to any physical variables in our models.

When addressing large-scale community patterns, morphodynamic models predict that species richness and abundance increase from reflective to more dissipative morphodynamic states because species are excluded from the extremes of the harsh swash climate and coarser sand conditions (Brazeiro 2001, McLachlan 2001). Although studies have confirmed this hypothesis (McLachlan and Dorvlo 2005, Barboza and Defeo 2015), ecological patterns, such as the importance of the effects of environmental drivers, may shift along spatial scales (Wiens 1989), especially on exposed sandy beaches (Defeo and de Alava 1995). For example, Giménez and Yanicelli (2000) proposed that the environmental variables driving the species-dependent distribution of the sandy beach crustaceans, Excirolana braziliensis, Excirolana armata and Emerita brasiliensis vary according to the sampling scale (between $30 \mathrm{~m}$ and $3 \mathrm{~km}$ ). However, this is not a general rule. Rodil et al. (2012) showed that that local scale investigations could be a feasible way to construct general predictive species-environmental models on sandy beaches. Ou results corroborated this hypothesis because they supported the morphodynamic models at the mesoscale.

The variability in species assemblage primarily results from the independent changes in the abundance of the individual species in response to variability in swash and particle grain size (McLachlan 1996). In this study, the variability in total abundance was primarily influenced by the species $S$. squamata and was significantly correlated to both swash and particle grain size $(\mathrm{p}<0.01)$. The polychaete species $S$. squamata, which is a suspension feeder that captures food particles above the sediment water interface, is widely distributed in the intertidal sediments of sandy beaches and lives in well-sorted grains (Dauer 1983). The more exposed area of the beach arc was dominated by the cirolanid, E. armata, which were virtually absent from the first transects. E. armata acts as a scavenger/predator and, at the macroscale, is highly substratum-specific to fine sands of beaches from dissipative to intermediate morphodynamic states (Defeo et al. 2001, Lozoya et al. 2010, Petracco et al. 2010). When only a single beach arc is investigated, the sand particle size emerges as the most immediate environment of the macrofauna (Defeo and McLachlan 2005). The sediment of Suja Beach varied from very fine sand $(0.09 \mathrm{~mm})$ to medium sand
$(0.34 \mathrm{~mm})$ and was included in the best fit for the total abundance and for the number of individuals of $S$. squamata. However, the distribution of E. armata was only related to the sediment sorting and not to particle grain size. Sediment sorting is controlled by hydrodynamic and/or geomorphological processes. Well-sorted sediments are typical of high-energy areas, whereas poorly sorted sediments are typical of low-energy areas (Gray 1981). Therefore, multiple environmental drivers (i.e. oxygen tension) are linked with the energy regimes of sandy beaches, and sorting can be used as a proxy of this variability. Here we have shown evidence that sorting, which operates over large spatial scales (Gray 2002), has a straight relationship with the distribution of E. armata, corroborating the harshness exclusion hypothesis even at mesoscales. In addition, regarding the across-shore variability, we found higher density and species richness at levels 1-5 than at levels 6-10 because cirolanid isopods and spionid polychaetes are typical of the littoral zone (Defeo and McLachlan 2005).

The presence of a pier at the sheltered end of Suja Beach could be a potential "amplifier" of the pattern found in macrofauna distribution because coastal structures could modify the wave regime and depositional processes of the beach arc. However, generalizing about the morphodynamics responses of sandy beaches to armouring impacts is very difficult because responses depend on the types of sediment, beach morphology, position in a drift cell, and local hydrodynamic regimes (Coyle and Dethier 2010). The sheltered intertidal areas next to piers can have a higher sedimentation rate and higher fine fraction percentage, which induce a lower permeability of sediment and a thin oxygenated layer (Gray 1981). However, in this case, the pier is a very short, totally permeable construction over a natural projection to the sea that is certainly not the main driver of macrofauna variability.

The relationship betweeen distance along the shore, species abundance and species richness indicated that the presence of a freshwater input in the middle area of the beach arc was not the main source of the variability alongshore. Note that in Figure 4 we captured a linear decrease in richness and abundance alongshore and not a disrupted pattern in the middle section of the beach arc, as could be expected if there was a major influence from freshwater input. This result was not expected (Lercari and Defeo 2003) and was probably related to the particular random positions of the equidistant transects sampled alongshore, which may not have captured a poor freshwater effect. However, future investigations should include temporal sampling to address the effect of the variability in the volume of freshwater discharge and the disruption of the spatial pattern described here.

Although the variability in sediment texture and beach face slope accounted for $37 \%$ of the total variance, a total of $63 \%$ of the variability in the community assemblage was not explained by the physical variables measured here. This indicates that some sources of variability (random noise, abiotic, biotic and/or the interactions) were not accounted for in our mod- 
el. The residual can also be a result of the mismatch between the scale of the environmental changes and biological response (Chapman et al. 2010, Barboza et al. 2015). We ran post hoc GLMs (using a Poisson distribution with log-link function) to model the total number of individuals and the number of $S$. squamata and E. armata, using distance along the shore as a predictor. We found a significant relationship in all the three models (Wald $t$ values $p<0.05$ ), with a negative correlation for the number of E. armata. The distance along the shore can express linear gradients (biotic and/or abiotic) that were not included in our model. Factors other than the morphodynamic variables included here may influence the pattern in community structures (Jaramillo and Lastra 2001, Rodil et al. 2012). For example, fine sediments have poor water circulation and often low oxygen tension, which can favour the presence of specific species (Gray 1981). In addition, medium and fine sands have more organic matter per unit area, so it is known that macrofauna density is usually higher (Gray 1981). The distribution of macrofauna alongshore may not only be influenced by physical drivers (Donn 1987), but also by the interaction between the physical and biological variables (Schoeman and Richardson 2002). Finally, here we predict an increase in the contribution of random noise to macrofauna variability when the spatial scales investigated are increased. This hypothesis should be further tested.

Our results indicate that physical variables are an important driver of community structure and species distribution, even under dissipative conditions and at mesoscales of log-spiral sandy beaches. The less exposed sheltered end of the beach was dominated by polychaetes, whereas the more exposed end was dominated by crustaceans, which confirms the swash exclusion hypothesis. The variability in macrofauna was mainly influenced by the polychaete $S$. squamata and the crustacean E. armata, which were both significantly related to the sediment texture or beach face slope. We can highlight that species abundance is a more sensitive community descriptor than species richness. Although predictions from the morphodynamic models were found at shortened physical gradients, the pattern of species richness was suppressed at mesoscales. These results corroborated previous data and supported that the scale of the investigation plays a crucial role in ecological modelling. Therefore, the species-morphodynamic models of sandy shores should be cross-validated against the changes in spatial scale and in the local habitat heterogeneity.

\section{ACKNOWLEDGEMENTS}

C.A.M. Barboza was supported by Coordenação de Aperfeiçoamento de Pessoal de Nível Superior (CAPES). T. Cabrini was supported by CNPq (Brazilian National Council for Scientific and Technological Development). G. Mattos and V.B. Skinner were supported by FAPERJ (Fundação de Amparo à Pesquisa do Estado do Rio de Janeiro). R.S. Cardoso was supported by FAPERJ and (CNPq).

\section{REFERENCES}

Ansell A.D. 1983. The biology of the genus Donax. In: McLachlan A., Erasmus T. (eds) Proceedings of Sandy beaches as ecosystems (Port Elizabeth, South Africa), pp. 607-636. https://doi.org/10.1007/978-94-017-2938-3_46

Barboza R.B., Defeo O. 2015. Global diversity patterns in sandy beach macrofauna: a biogeographic analysis. Sci. Rep. 5: 14515. https://doi.org/10.1038/srep14515

Barboza C.A.M., Martins C.C., Lana P. 2015. Dissecting the distribution of brittle stars along a sewage pollution gradient indicated by organic markers. Mar. Pollut. Bull. 100: 438-444. https://doi.org/10.1016/j.marpolbul.2015.08.008

Barton K. 2014. MuMIn: Multi-ModelInference. R Package Version 1.10.0. http://CRAN.R-project.org/package=MuMIn

Brazeiro A., 1999. Community patterns in sandy beaches of Chile: richness, composition, distribution and abundance of species. Rev. Chil. Hist. Nat. 72: 93-105.

Brazeiro A. 2001. Relationship between species richness and morphodynamics in sandy beaches: what are the underlying factors? Mar. Ecol. Prog. Ser. 224: 35-44.

Bremmer J.M. 1983. Properties of Logarithmic Spiral Beaches with Particular Reference to Algoa Bay. In: McLachlan A., Erasmus T. (eds) Proceedings of Sandy beaches as ecosystems (Port Elizabeth, South Africa), pp. 97-113. https://doi.org/10.1007/978-94-017-2938-3_6

Burnham K.P., Anderson D.R. 2002. Model Selection and Multimodel Inference: A Practice Information-Theoretic Approach. Springer, New York, 488 pp.

Cardoso S.R., Mattos G., Caetano C.H.S., et al. 2012. Effects of environmental gradients on sandy beach macrofauna of a semienclosed bay. Mar. Ecol. 33: 106-116. https://doi.org/10.1111/j.1439-0485.2011.00457.x

Chapman M.G., Tolhurst T.J., Murphy R.J., et al. 2010. Complex and inconsistent patterns of variation in benthos, micro-algae and sediment over multiple spatial scales. Mar. Ecol. Prog. Ser. 398: 33-47. https://doi.org/10.3354/meps08328

Coyle J.M., Dethier M.N. 2010. Review of shoreline armoring literature, In: Shipman H., Dethier M.N., Gelfenbaum G., et al. (eds). Puget Sound Shorelines and the Impacts of ArmoringProceedings of a State of the Science Workshop (Richland, Washington), pp. 239-258.

Dahl E. 1952. Some aspects of the ecology and zonation of the fauna of sandy beaches. Oikos 4: 1-27. https://doi.org/10.2307/3565072

Dauer D.M. 1983. Functional morphology and feeding behavior of Scolelepis squamata (Polychaeta: Spionidae). Mar. Biol. 77: 279-285. https://doi.org/10.1007/BF00395817

Defeo O., de Alava A. 1995. Effects of human activities on longterm trends in sandy beach populations: the wedge clam Donax hanleyanus in Uruguay. Mar. Ecol. Prog. Ser. 123: 73-82. https://doi.org/10.3354/meps 123073

Defeo O., McLachlan A. 2005. Patterns, process and regulatory mechanisms in sandy beach macrofauna: a multi-scale analysis. Mar. Ecol. Prog. Ser. 295: 1-20. https://doi.org/10.3354/meps295001

Defeo O., Rueda M. 2002. Spatial structure, sampling design and abundance estimates in sandy beach macroinfauna: some warnings and new perspectives. Mar. Biol. 140: 1215-1225. https://doi.org/10.1007/s00227-002-0783-z

Defeo O., Gómez J., Lercari D. 2001. Testing the swash exclusion hypothesis in sandy beach populations: the mole crab Emerita brasiliensis in Uruguay. Mar. Ecol. Prog. Ser. 212: 159-170. https://doi.org/10.3354/meps212159

Defeo O., Lercari D., Gómez J. 2003. The role of morphodynamics in structuring sandy beach populations and communities: what should be expected? J. Coast. Res. 59: 352-362.

Degraer S., Volckaert A., Vincx M. 2003. Macrobenthic zonation patterns along a morphodynamical continuum of macrotidal, low bar/rip and ultradissipative sandy beaches. Est. Coast Shelf Sci. 56: 459-468.

https://doi.org/10.1016/S0272-7714(02)00195-6

Donn T.E. 1987. Longshore distribution of Donax serra in two logspiral bays in the eastern Cape, South Africa. Mar. Ecol. Prog. Ser. 35: 217-222. https://doi.org/10.3354/meps035217

Dugan J.E., Hubbard D.M. 2010. Ecological effects of coastal ar- 
moring: A summary of recent results for exposed sandy beaches in southern California. In: Shipman H., Dethier M.N., Gelfenbaum G., et al. (eds). Puget Sound Shorelines and the Impacts of Armoring. Proceedings of a State of the Science Workshop (Richland, Washington), pp. 187-194.

Emery K.O. 1961. A simple method of measuring beach profiles. Limnol. Oceanogr. 6: 90-93. https://doi.org/10.4319/1o.1961.6.1.0090

Fernandes R.S.R., Soares-Gomes A. 2006. Community structure of macrobenthos in two tropical sandy beaches with different morphodynamic features, Rio de Janeiro, Brazil. Mar. Ecol. 27: 160-169. https://doi.org/10.1111/j.1439-0485.2006.00093.x

Folk R.L., Ward W.C. 1957. Brazos river bar: a study in the significance of grain size parameters. J. Sediment Petrol 27: 3-26. https://doi.org/10.1306/74D70646-2B21-11D7$8648000102 \mathrm{C} 1865 \mathrm{D}$

Fragoso M. 1999. Estudo numérico da circulação marinha da região das Baías de Sepetiba e Ilha Grande (RJ). Master thesis. Universidade de São Paulo, 115 pp.

Gandara-Martins A.L., Borzone C.A., Guilherme P.D.B., et al. 2014. Spatial Effects of a Washout on Sandy Beach Macrofauna Zonation and Abundance. J. Coast. Res. 31: 1459-1468.

Giménez L., Yannicelli B. 2000. Longshore patterns of distribution of macroinfauna on a Uruguayan sandy beach: an analysis at different spatial scales and of their potential causes. Mar. Ecol. Prog. Ser. 199: 111-125. https://doi.org/10.3354/meps 199111

Gray J.S. 1981. The ecology of marine sediments: an introduction to the structure and function of benthic communities. Cambridge University Press, Cambridge, $225 \mathrm{pp}$.

Gray J.S. 2002. Species richness of marine soft sediments. Mar. Ecol. Prog. Ser. 244: 285-297. https://doi.org/10.3354/meps 244285

Harris L., Campbell E.E., Nel R., et al. 2014. Rich diversity, strong endemism, but poor protection: addressing the neglect of sandy beach ecosystems in coastal conservation planning. Divers. Distrib. 20: 1120-1135. https://doi.org/10.1111/ddi.12226

Jaramillo E., Lastra M. 2001. Suspension feeders on sandy beaches. In: Reise K. (ed.), Ecological Comparisons of Sedimentary Shores. Ecological Studies 151. Springer, pp. 61-72. https://doi.org/10.1007/978-3-642-56557-1 4

Lastra M., McLachlan A. 1996. Spatial and temporal variations in recruitment of Donax serra Röding (Bivalvia: Donacidae) on an exposed sandy beach of South Africa. Rev. Chil. Hist. Nat. 69: 631-639.

LeBlond P.H. 1979. An Explanation of the Logarithmic Spiral Plan Shape of Headland-Bay Beaches. J. Sed. Petrol. 49: 1093-1100.

Legendre P., Gallegher E.D. 2001. Ecologically meaningful transformations for ordination of species data. Oecologia 129: 271-280. https://doi.org/10.1007/s004420100716

Lercari D., Defeo O. 2003 Variation of a sandy beach macrobenthic community along a human-induced environmental gradient. Est. Coast. Shelf Sci. 58: 17-24. https://doi.org/10.1016/S0272-7714(03)00043-X

Lozoya J.P., Gómez J., Defeo O. 2010. Modelling large-scale effects of estuarine and morphodynamic gradients on distribution and abundance of the sandy beach isopod Excirolana armata. Est. Coast. Shelf Sci. 87: 472-478 https://doi.org/10.1016/j.ecss.2010.02.005

McLachlan A. 1983. Sandy beach ecology: a review. In: McLachlan A., Erasmus T. (eds) Proceedings of Sandy beaches as ecosystems (Port Elizabeth, South Africa), pp. 321-380. https://doi.org/10.1007/978-94-017-2938-3 25

McLachlan A. 1990. Dissipative beaches and macrofauna communities on exposed intertidal sands. J. Coast. Res. 6: 57-71.
McLachlan A. 1996. Physical factors in benthic ecology: effects of changing sand particle size on beach fauna. Mar. Ecol. Prog. Ser. 131: 205-217. https://doi.org/10.3354/meps 131205

McLachlan A. 2001. Coastal beach ecosystems. In: Lewin R. (ed.), Encyclopedia of Biodiversity. Academic Press, pp. 741-751. https://doi.org/10.1016/B0-12-226865-2/00051-1

McLachlan A., Brown A.C. 2006. The Ecology of Sandy Shores. Academic Press, Burlington. 373 pp.

McLachlan A., Dorvlo A. 2005. Global patterns in sandy beach macrobenthic communities. J. Coast. Res. 21: 674-687. https://doi.org/10.2112/03-0114.1

McLachlan A., Hesp D. 1984. Faunal response to morphology and water circulation of a sandy beach with cusp. Mar. Ecol. Prog. Ser. 19: 133-144 https://doi.org/10.3354/meps019133

McLachlan A., Jaramillo E. 1995. Zonation on sandy beaches. Oceanogr. Mar. Biol. Ann. Rev. 33: 305-335.

Oksanen J., Blanchet F.G., Kindt R., et al. 2015. vegan: Community Ecology Package. R package version 2.3-0. http://CRAN.R-project.org/package=vegan

Petracco M., Cardoso R.S., Corbisier T.N. 2010. Population biology of Excirolana armata (Dana, 1853) (Isopoda, Cirolanidae) on an exposed sandy beach in Southeastern Brazil. Mar. Ecol. 31: 330-340. https://doi.org/10.1111/j.1439-0485.2009.00341.x

R Development Core Team, 2014. R: A Language and Environment for Statistical Computing. R Foundation for Statistical Computing, Vienna, Austria. http://www.R-project.org

Rao C.R. 1964. The use and interpretation of principal component analysis in applied research. Sankhyā: Indian J. Stat. A 26: 329-358.

Rodil I.F., Compton T.J., Lastra M. 2012. Exploring Macroinvertebrate Species Distributions at Regional and Local Scales across a Sandy Beach Geographic Continuum. PLoS ONE 7: e39609. https://doi.org/10.1371/journal.pone.0039609

Salvat B. 1964. Les conditions hydrodynamics interstitielles des sediments meubles intertidaux et la repartition de la fauna endogee. C. R. Acad. Sci. 259: 1576-1579.

Schoeman D.S., Richardson A.J. 2002. Investigating biotic and abiotic factors affecting recruitment of an intertidal clam on an exposed sandy beach using a generalized additive model. J. Exp. Mar. Biol. Ecol. 276: 67-81. https://doi.org/10.1016/S0022-0981(02)00239-3

Schlacher T.A., Thompson L. 2013. Spatial structure on oceanexposed sandy beaches: faunal zonation metrics and their variability. Mar. Ecol. Prog. Ser. 478: 43-55. https://doi.org/10.3354/meps10205

Schlacher T.A., Schoeman D.S., Dugan J., et al. 2008. Sandy beach ecosystems: key features, sampling issues, management challenges and climate change impacts. Mar. Ecol. 29: 70-90. https://doi.org/10.1111/j.1439-0485.2007.00204.x

Signorini S.R. 1980. A Study of The Circulation in Bay of Ilha Grande and Bay of Sepetiba Part I, A Survey of the Circulation Based on Experimental Field Data. Bol. Inst. Oceanogr. 29: 41-55. https://doi.org/10.1590/S0373-55241980000100004

Venables W.N., Ripley B.D. 2002. Modern Applied Statistics with S. Springer, New York, $495 \mathrm{pp}$ https://doi.org/10.1007/978-0-387-21706-2

Wiens J.A. 1989. Spatial scaling in ecology. Funct. Ecol. 3: 385-397. https://doi.org/10.2307/2389612

Zuur A.F., Ieno E.N., Walker N.J., et al. 2009. Mixed Effects Models and Extensions in Ecology with R. Springer, New York. 574 pp. https://doi.org/10.1007/978-0-387-87458-6 